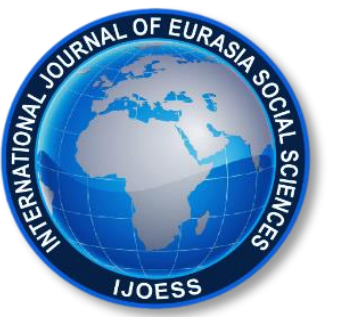

International Journal of Eurasia Social Sciences

Vol: 11, Issue: 39, pp. (69-91).

Article Type: Research article

Received: 22.05.2019 Accepted: 19.03.2020

\title{
DEVELOPMENT OF DIVERGENT THINKING SELF-ASSESSMENT SCALE
}

\author{
Fatih ORDU \\ Ph.D. Student, Işık University Social Sciences Institute Program of Clinical Psychology, Turkey, \\ fatihordu@yahoo.com \\ ORCID: 0000-0002-3969-747X \\ Mustafa Kemal YÖNTEM \\ Ph.D., Nevsehir Haci Bektas Veli University, Turkey, mustafa.yontem@nevsehir.edu.tr \\ ORCID: 0000-0001-7620-0971
}

\begin{abstract}
The aim of this study is to develop a scale for determining the divergent thinking self-assessment levels of adults over 18 years of age. In line with the aim of the present study, a 28-item-trial form was applied to the participants. Exploratory factor analysis based on the method of oblique rotation revealed that the scale had a 21 -item and two-factor components structure. Subdimensions are entitled as rationality and subjectivity. The eigenvalue of the rationality subdimension was found to be 6.90 . The eigenvalue of the subjectivity sub-dimension was found to be 3.94. The total variance of the two-factor structure was found to be about $50.66 \%$. The Cronbach coefficient score for the whole scale was.91. The Cronbach coefficient reliability scores for the sub-scales of rationality and subjectivity were .92 and .85 , respectively. Moreover, item correlation coefficients were above .50 for all the items of the form. Consequently, validity and reliability analysis indicate that the final form can measure the levels of divergent thinking selfassessment of the participants. The Divergent Thinking Self-Assessment Scale may provide an opportunity to reveal whether there is a relationship between self-assessment scale and performance assessment scale on divergent thinking, which can be a suggestion for further studies. The Divergent Thinking Self-Assessment Scale is considered to contribute to the studies related to creativity and divergent thinking.
\end{abstract}

Keywords: Divergent thinking, divergent thinking self-assessment, scale development. 


\section{INTRODUCTION}

Divergent thinking is associated with creativity (Ferrandiz et al., 2017; Heller, 2004). According to Siegel and Bugg (2016), creativity is mainly measured with divergent thinking that assesses the potential for creative thinking. Aslan (2001) states that creativity is mental processes that can come up with a product that has its own characteristics and include the features for solving existing problems. Kaufman (2002) considers divergent thinking as generating many new and different ideas by using available and existing knowledge. On the other hand, Heller (2004) notes that divergent thinking is an indicator of creativity. Ferrandiz et. al., (2017) states that divergent thinking skills are of top priority for creativity. In addition; Lee (2004) states that divergent thinking is useful depending on the type of problems and divergent thinking skills have a close relationship with creativity skills which includes the processes of creative thinking and coming up with new products or ideas.

Different tests have been developed to measure levels of divergent thinking skills in the literature. For example, Guilford (1982) aimed to measure divergent thinking skills and developed The Alternative Uses Test. The divergent thinking test of Guilford included 4 sub-dimensions: Fluency, Flexibility, Elaboration, and Originality. Torrance also developed a test to measure divergent thinking skills. The test was named as ATTA, which stands for the Abbreviated Torrance Test for Adults. Torrance developed the test following the approach of Guilford and used elaboration, originality, fluency, and flexibility sub-dimensions in the test (Shen and Lai, 2014). Remote Associates Test developed by Mednick (1968) was also another measure of divergent thinking. The test was developed in 1962 and consisted of 30 items. Bowden and Beeman (2003) improved the Remote Associates Test and reformed it by using a total of 144 items. The Remote Associates Test is adapted to Turkish by Özen et. al. (2015).

In addition; there are different scales to measure creative thinking which related to divergent thinking. Lucas (2016) defined three dimensions of power, width, and depth associated with the assessment of creativity. Power is the level of independence that students demonstrate according to needs or appropriate conditions. Width is the tendency to apply creativity in new contexts or a new field. Depth is complexity and time management.

Hawthorne et al. (2016) have sought to objectively measure and develop an individual's creative capacity in a real-world environment. They were also interested in basic features and changes in brain function as part of the measurement. Similarly, they created three different evaluation versions, each consisting of twelve steps and tasks. In these processes, design solutions, practical evaluation, needs recognition and adaptability were evaluated. The Inventory of Creative Activities and Achievements (ICAA) is a broad-based and multifaceted psychometric tool for assessing real-world creativity in various areas and levels of achievement (Diedrich et al., 2018). The ICAA evaluate trends for future developments as well as evaluating creative activities and achievements. It was proposed that the scale be adapted to the specific objectives of real-life creativity research. 
When all these measurement tools were analyzed, it was discovered that all these measures are tools for assessing performance based on the data obtained from norm groups. In other words, measures developed within the scope of divergent thinking generally assess the level of these skills. However, to our knowledge, there is not an assessment tool that aims to measure the self-assessment levels of the individuals related to divergent thinking skills. The scale developed for this study does not offer a performance assessment. The scale developed for this study aims to evaluate self-assessment levels of the individuals within the context of divergent thinking. In this way, it was aimed to reveal to what extent the individuals consider themselves sufficient in terms of divergent thinking. Divergent thinking is associated with coming up with creative, rational, and original solutions to problems. Self-assessment levels about divergent thinking may be efficient in the decision-making process of individuals. Reisman et al. (2016), suggest that individuals have developed awareness about themselves while evaluating themselves during the measurement process. In this regard, it is thought that the scales that allow evaluating the self-assessment levels of the individuals related to divergent thinking will contribute to the decision-making process of the individuals.

\section{METHOD}

\section{Research Group}

This research was conducted with two different samples. The first group included 509 participants from 7 different regions of Turkey. Data from the first group was used for factor analyses and reliability analyses. The second group included 86 female (\%55.13) and 70 male (\%44.87) university students $(n=156)$. Data from the second group was used for criterion validity. The demographic information of the first group participants is as shown in Table 1 below.

Table 1. Distribution of Research Group by Age, Education, and Gender

\begin{tabular}{cccc}
\hline & Variable & Group 1 & Percentage (\%) \\
\hline \multirow{2}{*}{ Gender } & Female & Number & 48,13 \\
& Male & 245 & 51.87 \\
\multirow{3}{*}{ Age } & $18-30$ & 264 & 61.29 \\
& $31-52$ & 312 & 38.71 \\
& & 197 & 1.17 \\
Education & Primary school & 6 & 0.98 \\
& Secondary school & 5 & 13.35 \\
& High school & 68 & 10.21 \\
& Associate degree & 52 & 69.74 \\
& Bachelor Degree & 355 & 4.52 \\
& Postgraduate & 23 & 100 \\
\hline
\end{tabular}




\section{Data Collection Tools}

\section{Thinking Style Scale (TSS)}

The scale adapted to Turkish by Sünbül (2004) was developed by Sternberg (1997). There are 5 factors in the scale. In this study, the dimensions of authentic and irregular thinking styles which are thought to be related to divergent thinking were used. While Cronbach's $\alpha$ internal consistency coefficient for authentic thinking style has been .75 , for irregular thinking style has been .68 in this study.

\section{Personal Information Form}

The personal information form, developed by the researchers, include questions on gender, age, education.

\section{Preparation of Scale Form}

The scale developed in this research is associated with Guilford's theories about creativity and mental processes. In addition; the special effort has been devoted to ensuring that the appropriate items have been selected for the target group. According to Cohen and Swerdlik (2015) instructions, evaluation and application of a powerful scale should be clear and understandable by everyone. To determine the items of divergent thinking self-assessment scale, national and international articles on divergent thinking have been analyzed (Guilford, 1982; Mednick,1968; Shen \& Lai, 2014; Özen et. al., 2015; Sünbül, 2004). To provide validity of the scale form, opinions were obtained from 4 experts who have Ph.D. degree in Clinical Psychology $(n=1)$ and Guidance and Psychological Counselling $(n=3)$. The Davies technique was used in the process of obtaining expert opinions. The measurement tool was designed as a four-point Likert type scale. According to this technique, expert opinions rate the items on the following four-point basis: (a) relevant, (b) requiring minor revision, (c) requiring major revision, and (d) not relevant. Index of Content Validity (CVI) is obtained by dividing the number of the experts ranking (a) relevant and (b) requiring minor revision by the total number of the experts. A CVI of .80 is acceptable (Davis, 1992; qtd. in Taşkın \& Akat, 2010). Then, a pilot interview was conducted with a group of 10 people and the feedbacks about the comprehensibility of the items were received from the participants in the face to face interview. A rating scale that is used in the Davies technique was utilized in the feedback process. After all these steps, a 27-item trial form was obtained. The categories used in the scale were "I do not agree", "partially agree", "mostly agree", and "completely agree".

\section{Data analysis}

First of all, the data of the study were analyzed and outliers are excluded from the study. Then, to determine construct validity of the scale, explanatory factor analysis was conducted with half of the data set $(n=254)$, and confirmatory factor analysis was conducted with the other half of the data set $(n=255)$ from first participant group. To determine the reliability of the scale, Cronbach $\alpha$ internal consistency coefficients and total item correlations were calculated for the whole data set $(n=509)$. 


\section{FINDINGS (RESULTS)}

\section{Findings Related to the Construct Validity}

First of all, explanatory factor analysis was carried out with half of the data set $(n=254)$ in order to calculate the construct validity of the Divergent Thinking Self-assessment Scale. The sample size of the current study was tested by the Kaiser-Meyer-Olkin (KMO) sample adequacy test to determine whether the data were appropriate for factor analysis and this value was found to be .90 . Such a result shows that the sample size of the study was adequate for factor analysis (Çokluk, Şekercioğlu \& Büyüköztürk, 2014; Şencan, 2005). In addition, the Bartlett's Test of Sphericity was conducted to determine whether the data were appropriate for component detection and the test indicated that factor analysis was useful with the data set $(p<.001)$ (Çokluk, Şekercioğlu \& Büyüköztürk, 2014; Şencan, 2005). Exploratory factor analysis was performed with the principal component analysis method (Tabachnick \& Fidell, 2007). The principal component analysis which is one of the most commonly used factor extraction techniques enables one to reveal the maximum variance in the data set (Tabachnick \& Fidell, 2007). Moreover, the oblique rotation method which simplifies the interpretation of factors was used in the explanatory factor analysis (Çokluk, Şekercioğlu, Büyüköztürk, 2014). As the scale was a multidimensional index type, exploratory factor analysis was performed with the Principal axis and oblique rotation method. In the exploratory factor analysis process, the condition that factor load value should be over .45 for each item and common factor variance should be over .45 was considered (Tabachnick \& Fidell, 2007). Theoretically provided a-four-factor analysis was conducted in the first explanatory factor analysis. However, as a result of ongoing analyses, a two-factor component with eigenvalues greater than 1, which has 21 items, was formed. Factor eigenvalue, variance and cumulative variance of the scale are as shown in table 2 and scree plot of factor eigenvalue is as shown in figure 1 below.

Table 2. Eigenvalue, Variance and Cumulative Variance of the Factors

\begin{tabular}{cccc}
\hline Factor & Eigenvalue & Variance & Cumulative variance \\
\hline 1 & 6.90 & 37.54 & 37.54 \\
2 & 3.74 & 13.11 & 50.66 \\
\hline
\end{tabular}




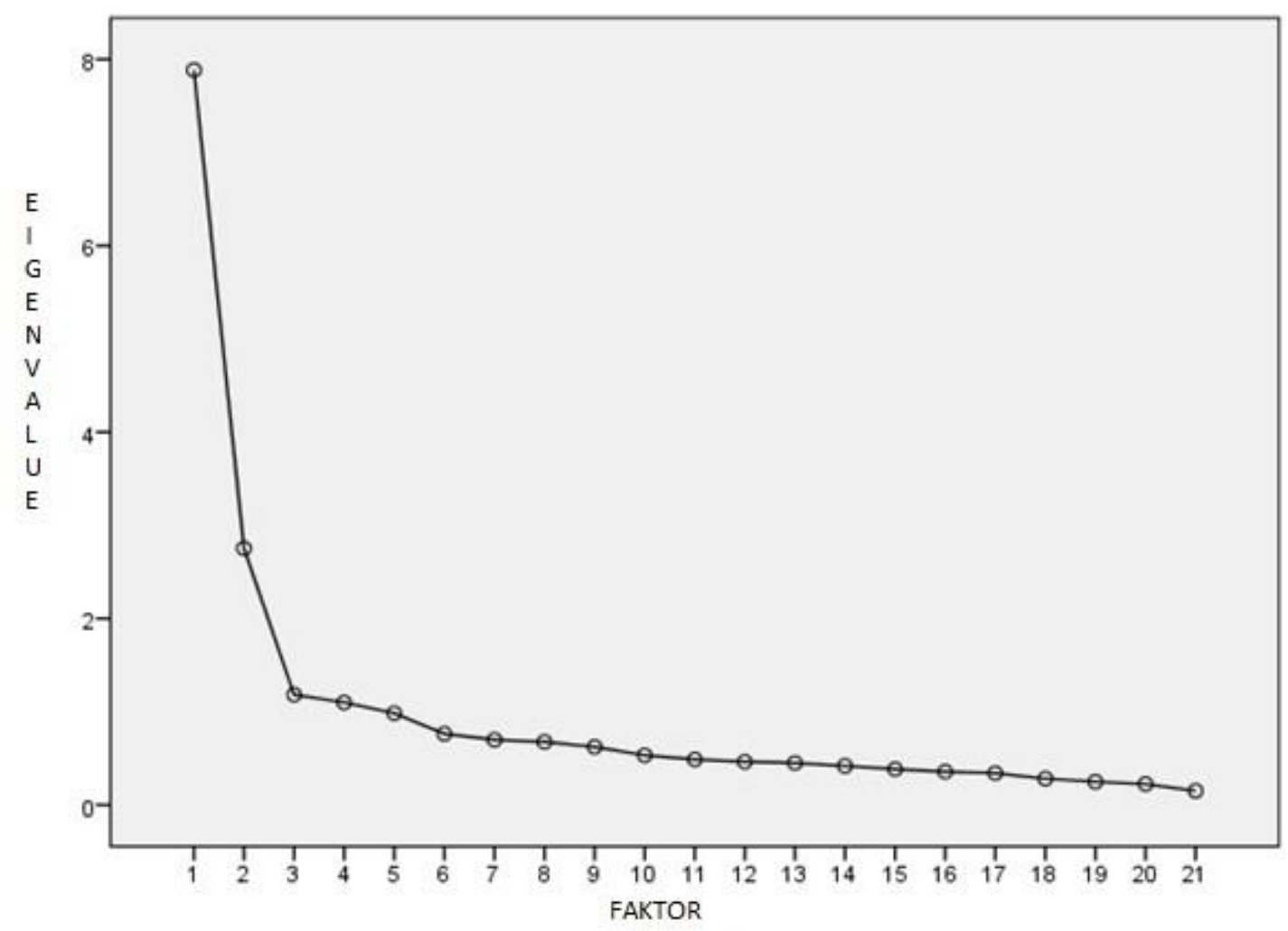

Figure 1. Scree Plot of Factor Eigenvalue

As shown in table 2, the two-factor component structure accounts for $50.66 \%$ of the total variance. The eigenvalues of the factors are 6.90 and 3.74, respectively. The distribution of the scale items with regard to factors is as shown in table 3 below.

Table 3. The Distribution of Items with regard to Factors and Common Factor Variance

\begin{tabular}{|c|c|c|c|c|}
\hline Item & Factor 1 & Factor 2 & $\begin{array}{l}\text { Common } \\
\text { factor } \\
\text { variance }\end{array}$ & $\begin{array}{l}\text { Total item } \\
\text { correlations }\end{array}$ \\
\hline 21. I can find a solution to a problem faster than anybody else & .78 & & .61 & .67 \\
\hline 20. It is easy for to understand complex events & .76 & & .59 & .73 \\
\hline 19. If there is a problem, I can solve it soon & .75 & & .57 & .70 \\
\hline 15. It is easy for me to find a way out against uncertainties & .70 & & .52 & .65 \\
\hline 28. If there is a problem, I find more solutions than others & .69 & & .52 & .65 \\
\hline 27. I can always sum something up very quickly & .68 & & .46 & .62 \\
\hline 17. I fully understand the causes of an event in a short time & .67 & & .47 & .62 \\
\hline $\begin{array}{l}\text { 16. I notice if there is even a slight similarity between the two } \\
\text { situations }\end{array}$ & .66 & & .50 & .64 \\
\hline 22. I can quickly estimate the results of an event & .65 & & .42 & .61 \\
\hline 26. I can develop a number of solutions to a problem & .65 & & .54 & .57 \\
\hline 18. It is almost impossible to deceive me & .63 & & .41 & .56 \\
\hline $\begin{array}{l}\text { 14. I understand if there is even a slight difference between the } \\
\text { two situations }\end{array}$ & .59 & & .47 & .60 \\
\hline 2. There is no problem in my life that I cannot cope with & .57 & & .32 & .48 \\
\hline
\end{tabular}


25. I can make more than one question sentence for an answer

24. I can add a third opinion against two opposing views

13. I can see other perspectives of an event that no one can see

8. I can pay attention to ideas that no one cares about

10. I can see similarities between what is thought to be different

7. My feelings and thoughts may be different from the majority in the face of an event

11. I can see differences between situations considered to be similar

6. Things that are worthless to the majority can be valuable to me

Faktor1: Rationalism, Faktor2: Authenticity.

\section{.55}

.52

.48

\begin{tabular}{lll} 
& .41 & .57 \\
& .38 & .53 \\
& .35 & .50 \\
.81 & .66 & .66 \\
.78 & .67 & .65 \\
.76 & .58 & .66 \\
.76 & .65 & .69 \\
.73 & .54 & .61 \\
\hline
\end{tabular}

As seen in table 2, factor load values of the items ranged from .48 to .81. and common factor variances ranged from .35 to .67 . The items found in the first factor constitute rationality sub-dimension and the items found in the second factor form subjectivity sub-dimension of the scale.

\section{Confirmatory Factor Analysis}

The validity of 21-item and 2-component factor formed after the explanatory factor analysis was tested with the Confirmatory Factor Analysis. In this phase, first-order confirmatory factor analysis was carried out with the other half of the data set $(n=255)$ without making any modifications. In the confirmatory factor analysis, theoretically acceptable modifications that can significantly contribute to $X^{2}$ values appeared to be between the items of 6. "Things that are worthless to the majority can be valuable to me." and 7. "My feelings and thoughts may be different from the majority in the face of an event." And the items; 14. "I understand if there is even a slight difference between the two situations." and 16. "I notice if there is even a slight similarity between the two situations." The model was modified with the output of the modification indices and it was found that there is a certain degree of latent correlation between the pair of items 6 and 7 ; and 14 and 16 . The goodness of fit indices are as shown in Table 4, and structural equation model is as shown in Figure 2.

Table 4. The Goodness of Fit Indices

\begin{tabular}{ccc}
\hline Indices & Acceptable fit & Model indices \\
\hline $\mathrm{X} 2$ & $\geq .05$ (Hair et. al., 2006) & .01 \\
$\mathrm{P}$ & $\leq 5$ (Sümer, 2000) & 3.39 \\
$\mathrm{x}^{2} / \mathrm{sd}$ & $\leq .08$ (Hair et. al., 2006) & .09 \\
$\mathrm{RMSEA}$ & $\leq .08$ (Hair et. al., 2006) & .08 \\
$\mathrm{SRMR}$ & $\geq .90$ (Hair et. al., 2006) & .92 \\
$\mathrm{NFI}$ & $\geq .90$ (Hair et. al., 2006) & .94 \\
$\mathrm{NNFI}$ & $\geq .90$ (Hair et. al., 2006) & .95 \\
$\mathrm{CFI}$ & $\geq .90$ (Hair et. al., 2006) & .80 \\
$\mathrm{GFI}$ & $\geq .90$ (Hair et. al., 2006) & .08 \\
$\mathrm{AGFI}$ &
\end{tabular}




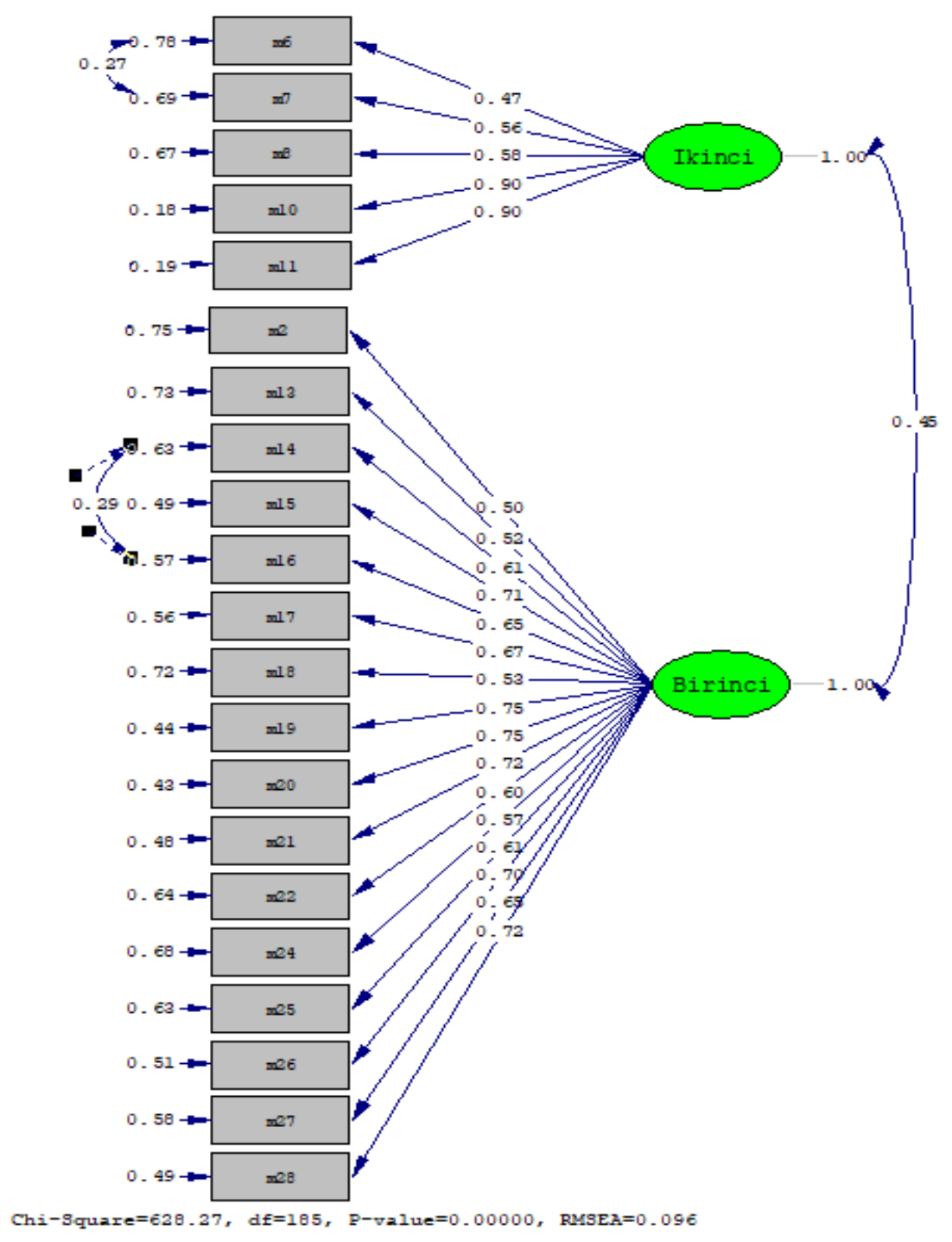

Figure 2. Standard Values after Modification

Table $4 . t$ and $\mathrm{R}^{2}$ Values of the Items

\begin{tabular}{lll}
\hline Item & t value & R2 \\
\hline 21. I can find a solution to a problem faster than anybody else & 12.96 & 0.52 \\
20. It is easy for to understand complex events & 13.89 & 0.57 \\
19. If there is a problem, I can solve it soon & 13.59 & 0.56 \\
15. It is easy for me to find a way out against uncertainties & 12.96 & 0.51 \\
28. If there is a problem, I find more solutions than others & 12.91 & 0.51 \\
27. I can always sum something up very quickly & 11.31 & 0.42 \\
17. I fully understand the causes of an event in a short time & 11.60 & 0.44 \\
16. I notice if there is even a slight similarity between the two & 12.21 & 0.43 \\
situations & 10.33 & 0.36 \\
22. I can quickly estimate the results of an event &
\end{tabular}


26. I can develop a number of solutions to a problem

18. It is almost impossible to deceive me

14. I understand if there is even a slight difference between the two situations

2. There is no problem in my life that I cannot cope with

25. I can make more than one question sentence for an answer

24. I can add a third opinion against two opposing views

13. I can see other perspectives of an event that no one can see

8. I can pay attention to ideas that no one cares about

10. I can see similarities between what is thought to be different

7. My feelings and thoughts may be different from the majority in the face of an event

11. I can see differences between situations considered to be similar

6. Things that are worthless to the majority can be valuable to me

$\begin{array}{ll}12.56 & 0.49 \\ 8.90 & 0.28 \\ 11.27 & 0.37\end{array}$

$8.24 \quad 0.25$

$10.55 \quad 0.37$

$9.79 \quad 0.32$

$8.95 \quad 0.27$

$10.24 \quad 0.33$

$17.71 \quad 0.82$

$9.91-0.31$

$17.52 \quad 0.81$

$8.32-0.22$

\section{Criterion Validity}

In order to determine the criterion validity, the relationship between DTSA and TSS was examined. For this purpose authentic thinking and irregular thinking sub-scales was used, which are belong to TSS.

Table 5. Corelation between DTSA and TSS Sub-scales.

\begin{tabular}{cccccc}
\hline & Factor1 & Factor2 & Divergent total & Irregular & Authentic \\
\hline Factor1 & 1 & & & & \\
Factor2 &, $450^{* *}$ & 1 & & & \\
Divergent total &, $958^{* *}$ &, $686^{* *}$ & 1 & 1 & \\
Irregular &, $487^{* *}$ &, $455^{* *}$ &, $542^{* *}$ &, $393^{* *}$ & 1 \\
Authentic &, $521^{* *}$ &, $417^{* *}$ &, $558^{* *}$ &, \\
\hline
\end{tabular}

$* *(p<.01)$.

In the present study, the DTSA was investigated in relation to irregular and authentic thinking styles. Significant correlations were found between the scores of the DTSA and other relevant constructs as shown in Table 5.

\section{Reliability}

To assess the validity of the sub-scale and the total scale, Cronbach $\alpha$ internal consistency was computed for each subscale and for the total scale. Cronbach $\alpha$ internal consistency values for sub-scales and for the total scale are presented in Table 5 below.

Table 5. Cronbach $\alpha$ Values for Sub-scales and for the Total Scale

\begin{tabular}{cc}
\hline Factor & Cronbach $\alpha$ \\
\hline The total scale & .92 \\
Factor1 & .91 \\
Factor2 & .85 \\
\hline
\end{tabular}


As shown in Table 5 above, the internal consistency for the sub-scales and for the whole scale was above .80 . Such a result was generally accepted as reliable in the literature (Hair et. al., 2006). Total item correlations

(Table 2 ) were found to be above .50, which indicates that the scale has internal validity.

\section{CONCLUSION and DISCUSSION}

As a result of exploratory factor analysis based on the method of oblique rotation, a 2-factor component emerged. These factors are called subjectivity ( 5 items) and fluency (16 items). Factor loads for items ranged from .48 to .81 and the scale has a variance of $50.66 \%$. Furthermore, the CFA results are acceptable. Correlations between the DTS and irregular thinking styles, authentic thinking styles were $.54, .56$ respectively $(p<.01)$. Considering the data of this study, it may be interpreted that the scale can measure the level of divergent thinking self-assessment of adult individuals.

The divergent thinking self-assessment scale, which was developed as a self-assessment tool, has two subdimensions as subjectivity and rationality. On the other hand, flexibility and elaboration sub-dimensions do not take place on the scale, which may be accepted as a limitation of the scale. Because, in the literature, the divergent thinking self-assessment scale of Guilford (1982), developed as a performance assessment scale, included rationality, flexibility, originality, and elaboration sub-dimensions.

The scale obtained from this study allows individuals to assess their divergent thinking skills. In particular, increasing the number of measurement tools that assess divergent thinking skills in relation to creativity may allow the development of models and theories related to the subject. The contribution of the psychometric approach should be provided to improve creativity (Zeng et al. 2011). In addition to the performance tests developed for divergent thinking skills, self-assessment tools can also contribute to the theories of creativity. Some studies showed that there is a strong correlation between self-assessment and performance assessment (Pintrich \& Groot, 1990) while some others showed that there is no correlation between self-assessment and performance assessment (Brackett et al. 2006). The Divergent Thinking Self-Assessment Scale may provide an opportunity to reveal whether there is a relationship between self-assessment scale and performance assessment scale on divergent thinking, which can be a suggestion for further studies. The Divergent Thinking Self-Assessment Scale is considered to contribute to the studies related to creativity and divergent thinking.

\section{ETHIC}

In this article, journal writing rules, publishing principles, research and publication ethics rules, journal ethics rules followed. Authors are responsible for any violations that may occur in the article. 


\section{REFERENCES}

Althuizen, N., Wierenga, B. \& Rossiter, J. (2010). "The Validity of Two Brief Measures of Creative Ability." Creatıvity Research Journal, 22(1): 53-61.

Aslan, E. (2001). "Torrance Yaratıcı Düşünce Testi'nin Türkçe Versiyonu.” M.Ü. Atatürk Eğitim Fakültesi Eğitim Bilimleri Dergisi. 14: 19-40.

Baer, J. (2011). “How Divergent Thinking Tests Mislead Us: Are the Torrance Tests Still Relevant in the 21st Century? The Division 10 debate". Psychology of Aesthetics, Creativity, and the Arts. 5(4): 309-313.

Bowden, E. M. \& Jung-Beeman, M. (2003). “Normative Data for 144 Compound Remote Associate Problems.” Behavior Research Methods, Instruments ve Computers, 35(4): 634-639.

Brackett, M. A., Rivers, S. E., Shiffman, S., Lerner, N. \& Salovey, P. (2006). "Relating Emotional Abilities to Social Functioning: A Comparison of Self-report and Performance Measures of Emotional Intelligence." Journal of Personality and Social Psychology, 91(4): 780-795. doi.org/10.1037/0022-3514.91.4.780

Büyüköztürk, Ş. (2002). "Faktör analizi: Temel kavramlar ve Ölçek Geliştirmede Kullanımı." Kuram ve Uygulamada Eğitim Yönetimi, 32: 470-483.

Büyüköztürk, Ş. (2011). Sosyal Bilimler İçin Veri Analizi El Kitabı. Ankara: Pegem Akademi Yayıncılık.

Chıld, D. (2006). The Essentials of Factor Analysis. London: Continuum.

Cohen, R.J. \& Swerdlık, M.E. (2015). Psikoloik Test ve Değerleme. Çev: Ezel Tavşancıl. Ankara: Nobel Yayınları.

Çokluk, Ö., Şekercioğlu, G. \& Büyüköztürk, Ş. (2014). Sosyal Bilimler Için Çok Değişkenli İstatistik SPSS ve LISREL Uygulamaları. Ankara: PEGEM Akademi Yayıncılık.

Diedrich, j., Jauk, E., Silvia, P. J., Gredlein, J.M., Neubauer, A.C., Benedek, M. (2018) Assessment of Real-Life Creativity: The Inventory of Creative Activities and Achievements (ICAA). Psychology of Aesthetics, Creativity, and the Arts. 12 (3)304-316

Ferrandiz, C., Ferrando, M., Soto, G., Sainz, M. \& Prieto, D.M. (2017). “Divergent Thinking and Its Dimensions: What We Talk About and What We Evaluate?" Anales de Psicologia. 33 (1): 40-47.

Guilford, J.P. (1982). “Cognitive Psychology's Ambiguities, Some Suggested Remedies.” Psychological Review. 89(1): 48-59.

Güngör, D. (2016). “Psikolojide Ölçme Araçlarının Geliştirilmesi ve Uyarlanması Kılavuzu.” Türk Psikoloji Yazıları, 19 (38): 104-112.

Dirlik, M.E. (2014). Ölçek Geliştirme Konulu Doktora Tezlerinin Test ve Ölçek Geliştirme Standartlarına Uygunluğunun İncelenmesi. Eğitimde ve Psikolojide Ölçme ve Değerlendirme Dergisi, 5(2): 62-78.

Erkuş, A., Sünbül, A., Sünbül, S.Ö., Yormaz, S. \& Aşiret, S. (2017). Psikolojide Ölçme ve Ölçek Geliştirme II. Ankara: Pegem Akademi.

Hair, Jr., J. F., Black, W. C., Babin, B. J., Anderson, R. E. \& Tatham, R. L. (2006). Multivariate Data Analysis (6th ed.). Upper Saddle River, NJ: Pearson Prentice Hall.

Hawthorne G., Saggar, M., Quintin, E.M., Bott N., Keinitz, E., Liu, N., Chien, Y.H., Hong, D., Reiss, A.L. (2016) Designing a Creativity Assessment Tool for the Twenty-First Century: Preliminary Results and Insights 
from Developing a Design-Thinking Based Assessment of Creative Capacity. Design Thinking Research.

111-123. doi.org/10.1007/978-3-319-19641-1_8.

Heller, K.A. (2004). "Identification of Gifted and Talented Students." Psychology Science, 46(3): 302 - 323.

Kaufman, J. C. (2002). Creativity and Confidence: Price of Achievement": Comment. American Psychologist. 57(5): 375-376.

Karakoç, F.Y. \& Dönmez, L. (2014). Ölçek Geliştirme Çalışmalarında Temel İlkeler. Tıp Eğitimi Dünyası. 5 (40): 3949.

Lee, Y. J. (2004). Effects of Divergent Thinking Training/Instructions on Torrance Tests of Creative Thinking and Creative Performance. Doktora Tezi, University of Tennessee.

Lucas, B. (2016) A Five-Dimensional Model of Creativity and its Assessment in Schools. Applied Measurement In Education. 29 (4) 278-290.

Mednick, S. A. (1968). "The Remote Associates Test." The Journal of Creative Behavior, 2(3): 213-214.

Özen, G., Doğan, A. \& Cinan, S. (2015). "Uzak Bağlantılar Testi: Norm ve Güvenirlik Çalışması." Psikoloji Çalışmaları Dergisi, 35:2-25.

Pintrich, P. R. \& De Groot, E. (1990). “Motivational And Self-Regulated Learning Components Of Classroom Academic Performance." Journal of Educational Psychology, 82(1): 33-40

Reisman, F., Keiser, L., Otti, O. (2016) Development, Use and Implications of Diagnostic Creativity Assessment App, RDCA - Reisman Diagnostic Creativity Assessment. Creativity Research Journal, 28(2) 177-187.

Shen, T., Lai, J.C. (2014). "Exploring the Relationship between Creative Test of ATTA and the Thinking of Creative Works" Procedia-Social and Behavioral Sciences (112): 557-566.

Siegel, J. \& Bugg, J. M. (2016). "Dissociating Divergent Thinking and Creative Achievement by Examining Attentional Flexibility and Hypomania." Psychology of Aesthetics, Creativity, and the Arts, 10(4): 416424.

Soper, D.S. (2017). "A-priori Sample Size Calculator for Structural Equation Models Software." Available from http://www.danielsoper.com/statcalc

Sümer, N. (2000). "Yapısal Eşitlik Modelleri: Temel Kavramlar ve Örnek Uygulamalar." Türk Psikoloji Yazıları, $3(6): 49-74$.

Sünbül, A.M. (2004). “Düşünme Stilleri Ölçeğinin Geçerlik ve Güvenirliği." Eğitim ve Bilim, 29 (132): 25-42.

Tabachnick, B. G. \& Fidell, L. S. (2007). Using Multivariate Statistics. New York: Pearson Education.

Zeng, L., Proctor, R.W. \& Salvendy, G. (2011). "Can Traditional Divergent Thinking Tests be Trusted in Measuring and Predicting Real-World Creativity?" Creativity Research Journal, 23:1, 24-37. 


\title{
IRAKSAK DÜŞÜNME ÖZ DEĞERLENDIRME ÖLÇEĞI’NIN GELIŞTiRILMESi
}

\author{
öz
}

Bu araştırmanın amacı, 18 yaş üstü, yetişkinlerin ıraksak düşünme öz değerlendirme düzeylerini belirlemeye yönelik bir ölçme aracı geliştirmektir. Iraksak düşünme becerileri, yaratıcı düşünme ve yenilikler üretme ile ilişkilidir. Iraksak düşüncenin değerlendirilmesi için geliştirilmiş farklı testler bulunmaktadır. $\mathrm{Bu}$ araştırmada geliştirilen ölçme aracında, birey kendisini değerlendirmektedir, kişiler kendilerini ıraksak düşünce bağlamında ne düzeyde yeterli gördüklerini ortaya koymaktadır. Çalışmanın amaçları doğrultusunda 28 maddeden oluşan deneme formu katılımcılara uygulanmıştır. Oblik döndürme yöntemine dayalı açımlayıcı faktör analizi çalışmaları ölçeğin 21 maddeli, iki faktörlü bir yapıya sahip olduğunu ortaya koymuştur. Alt boyutlar; akıcılık ve öznellik olarak adlandırılmıştır. Ölçeğin akılcılık alt boyutunun özdeğeri 6.90, öznellik alt boyutunun özdeğeri 3.94 olarak bulunmuştur. Elde edilen iki faktörlü yapının toplam varyansı \% 50.66 düzeyindedir. Ölçeğin tamamına ait cronbach $\alpha$ güvenirlik katsayısı 91 iken alt boyutlara ait cronbach $\alpha$ güvenirlik katsayısı akılcılık için .92 öznellik için .85 'dir. Ayrıca madde toplam korelasyonları tüm maddeler için .50’nin üzerindedir. Sonuç olarak geçerlik ve güvenirliğe ilişkin bulgular ulaşılan nihai formun, ıraksak düşünce öz değerlendirme düzeyini ölçebileceğine işaret etmektedir. Bu çalışmadan elde edilen ölçek, bireylerin ıraksak düşünme becerilerini değerlendirmelerine olanak sağlamaktadır. Iraksak düşünme gibi farklı düşünme becerilerini değerlendiren ölçüm araçlarının sayısının arttırıması, konu ile ilgili modellerin ve teorilerin geliştirilmesine olanak sağlayabilir. Iraksak Düşünme Öz Değerlendirme Ölçeği'nin yaratıcılık ve ıraksak düşünme ile ilgili çalışmalara katkı sağlayacağı düşünülmektedir.

Anahtar Kelimeler: Iraksak düşünme, Iraksak düşünme öz değerlendirme, Ölçek geliştirme. 


\section{Giriş}

Iraksak düşünme yaratıcılık becerileriyle ilişkilidir (Ferrandiz ve diğerleri, 2017; Heller, 2004). Aslan (2001) yaratıcılığın, kendine has özellikleri olan bir ürün ortaya koyabilen ve var olan sorunların çözümüne yönelik özellikleri içeren zihinsel süreçler olduğunu belirtmektedir. Siegel ve Bugg'a (2016) göre, yaratııılık bilimsel araştırmalarda ağırlıklı olarak yaratıcı düşünce potansiyelini değerlendiren ıraksak düşünceyle ölçülür. Kaufman (2002) mevcut verilerden yola çıkarak yeni, farklı ve çok sayıda fikirler geliştirilmeyi ıraksak düşünme (divergent thinking) olarak değerlendirmektedir. Heller (2004) ıraksak düşüncenin bir yaratıclık göstergesi olduğunu ifade etmektedir. Ferrandiz ve diğerleri (2017) yaratıcılıkta ıraksak düşünme becerilerinin öncelikli olduğunu düşünmektedir. Lee ise bunlara ek olarak (2004) Iraksak düşünmenin, problemin türüne göre işe yarar taraflarının olduğunu ve ıraksak düşünme becerilerinin yaratıcı düşünme ve yeni bir fikir veya ürün ortaya koymaya yönelik üretkenlik becerileriyle yakından ilişkili olduğunu belirtmektedir.

Görüldüğü üzere ıraksak düşünce problemlere karşı yaratıcı akılcı ve özgün çözüm yolları önerebilmek ile ilişkilidir. Bireylerin ıraksak düşünce ile ilgili öz yeterlikleri karar alma süreçlerinde etkili olabilir. Bu kapsamda değerlendirildiğinde ıraksak düşünmeyle ilgili bireylerin özyeterliklerini değerlendirmeye imkân sağlayan ölçeklerin bireyle ilgili karar alma süreçlerine katkı sağlayacağı düşünülmektedir.

Iraksak düşüncenin ölçümlenmesi amacı ile farklı testler geliştirilmiştir. Örneğin Guilford (1982) farklı düşünme becerilerini ölçmeyi amaçlayarak Alternatif Kullanım Testi'ni (The Alternative Uses Test) geliştirmiştir. Guilford ıraksak düşünme testinde akııılık, esneklik, ayrıntılandırma ve özgünlük olarak dört farklı alt boyuta yer vermiştir. Iraksak düşünmeyle ilgili test geliştiren bir diğer araştırmacı ise Torrance'dir. Geliştirilen testin adı ilk harflerin kısaltmasıyla ATTA (Abbreviated Torrance Test For Adults) olarak belirlenmiştir. Torrance, Guilford'un yaklaşımına göre bir model oluşturmuş ve geliştirdiği testte akıcılık, esneklik, ayrıntılandırma ve özgünlük olarak dört alt boyuta yer vermiştir (Shen ve Lai, 2014).

Iraksak düşünmeyle ilgili geliştiren bir diğer test olan Uzak Bağlantılar Testi (Remote Associates Testi) Mednick (1968) tarafından 1962 yılında, toplamda 30 madde olarak geliştirilmiştir. Bowden ve Beeman (2003) Uzak Bağlantılar Testi'ni genişleterek 144 maddeden oluşan bir test formu oluşturmuşlardır. Uzak Bağlantılar Testi Özen ve diğerleri (2015) tarafından Türkçeye uyarlanmıştır.

Alanyazında yer alan tüm bu ölçme araçlarına baktığımızda, ölçeklerin performans ölçümüne yönelik araçlar olduğu ve norm gruplarından elde edilen veriler doğrultusunda değerlendirmeler yapıldığı görülmektedir. Başka bir ifade ile ıraksak düşünce kapsamında geliştirilen ölçme araçları genel olarak bu becerilerin düzeyini ölçmektedir. Ancak bilindiği kadarı ile ıraksak düşünce konusunda bireylerin öz yeterliklerini ölçmeyi amaçlayan bir ölçme aracı bulunmamaktadır. Bu araştırmada geliştirilen ölçek bir performans ölçümü yapmamaktadır. Araştırma kapsamında geliştirilen ölçeğin amacı bireylerin ıraksak düşünce bağlamında öz yeterlik düzeylerinin değerlendirilmesidir. Bu sayede bireylerin kendilerini ıraksak düşünce bağlamında ne düzeyde yeterli gördükleri ortaya konulmaya çalışılmıştır. 


\section{YÖNTEM}

\section{Araştırma Grubu}

Araştırma iki farklı grupla yürütülmüştür. Birinci grup Türkiye'nin 7 farklı bölgesinden 509 katılımcıdan oluşmaktadır. Birinci gruptan toplanılan veriler faktör analizleri ve güvenirlik analizi için kullanılmıştır. İkinci araştırma grubu ise 86 kadın (\%55.13) ve 70 erkek (\%44.87) üniversite öğrencisinden oluşmaktadır ( $n=156)$. İkinci araştırma grubundan toplanılan veriler ölçüt geçerliği için toplanmıştır. Birinci araştırma grubuna ait demografik bilgiler Tablo 1 de görüldüğü gibidir.

Tablo 1. Birinci Araştırma Grubuna Ait Yaş, Eğitim ve Cinsiyet Bilgileri.

\begin{tabular}{|c|c|c|c|}
\hline \multirow{2}{*}{\multicolumn{2}{|c|}{ Değişken }} & \multicolumn{2}{|c|}{ Grup 1} \\
\hline & & Sayı & Yüzde (\%) \\
\hline \multirow{2}{*}{ Cinsiyet } & Kadın & 245 & 48,13 \\
\hline & Erkek & 264 & 51.87 \\
\hline \multirow{2}{*}{ Yaş } & $18-30$ & 312 & 61.29 \\
\hline & $31-52$ & 197 & 38.71 \\
\hline \multirow{7}{*}{ Eğitim } & İlkokul & 6 & 1.17 \\
\hline & Ortaokul & 5 & 0.98 \\
\hline & Lise & 68 & 13.35 \\
\hline & Üniversite öğrencisi & 52 & 10.21 \\
\hline & Lisans mezunu & 355 & 69.74 \\
\hline & Lisansüstü & 23 & 4.52 \\
\hline & Total & 509 & 100 \\
\hline
\end{tabular}

\section{Veri Toplama Araçları}

\section{Düşünce Stilleri Ölçeği}

Sternberg (1997) tarafından geliştirilen ölçeğin Türkçe uyarlama çalışmaları Sünbül (2004) tarafından gerçekleştirilmiştir. Ölçek 5 alt boyuttan oluşmaktadır. Bu araştırma kapsamında ölçeğin yalnızca öznellik ve ayırt edicilik alt boyuları kullanılmıştır ve Cronbach's $\alpha$ değeri öznellik boyutu için .75, ayırt edicilik boyutu için .68 olarak bulunmuştur.

\section{Kişisel Bilgi Formu}

Araştırmacılar tarafından geliştirilen bu formda cinsiyet, yaş ve eğitim bilgilieri alınmıştır.

\section{Ölçek Formunun Hazırlanması}

$\mathrm{Bu}$ araştırmada geliştirilen ölçek model olarak Guilford'un yaratıcılık ve zihinsel süreçlerle ilgili teorileriyle ilişkilendirilmektedir. Ayrıca geliştirilen maddelerin ölçme yapılacak gruba uygun olarak belirlenmesi yönünde 
çaba gösterilmiştir. Cohen ve Swerdlık'e (2015) göre güçlü bir ölçekte talimatlar, değerlendirme ve uygulama herkes tarafından açık ve anlaşılır olmalıdır. Iraksak Düşünme Öz Yeterlik Ölçeği formunda yer alacak maddelerin oluşturulması amacıyla; ıraksak düşünmeye ilişkin ulusal ve uluslararası çalışmalar incelenmiştir (Guilford, 1982; Mednick,1968; Shen and Lai, 2014; Özen ve diğ.,2015; Sünbül, 2004). Ölçek formunun geçerliğinin sağlanması amacıyla Klinik Psikoloji $(n=1)$ ve Rehberlik ve Psikolojik Danışmanlık $(n=3)$ alanlarında doktora derecesine sahip olan 4 uzmandan görüş alınmıştır. Ölçme aracı, 4 kategorili likert tipi ölçek şeklinde tasarlanmıştır. Ölçek kategorileri; “Katılmıyorum (1)”, “Kısmen Katılıyorum (2)”, “Çoğunlukla Katılıyorum (3)” ve “Tamamen Katılıyorum (4)” olarak belirlenmiştir.

\section{Veri analizi}

Araştırmada öncelikle veri seti incelenmiş ve aykırı uç değerler veri setinden çıkarılmıştır. Ardından ölçeğin yapı geçerliğinin ortaya konulması amacı ile 509 kişilik veri setinin yarısı ile $(n=254)$ açımlayıcı faktör analizi; diğer yarııı ile $(n=255)$ doğrulayıcı faktör analizi gerçekleştirilmiştir. Güvenilirlik analizi kapsamında ise veri setinin tamamı ile $(n=509)$ cronbach $\alpha$ iç tutarlık katsayıları ve madde toplam korelasyonları incelenmiştir.

\section{BULGULAR}

\section{Yapı Geçerliğine Ait Bulgular}

IDÖDÖ’nin yapı geçerliğini incelemek için öncelikle veri setinin yarısı ile $(n=254)$ açımlayıcı faktör analizi gerçekleştirilmiştir. Verilerin faktör analizine uygun olup olmadığını belirlemek amacıyla örneklem büyüklüğü Kaiser- Meyer-Olkin (KMO) örneklem yeterliği testi ile analiz edilmiştir ve bu değer .90 olarak bulunmuştur. Bu durum iyi bir örneklem büyüklüğüne ulaşıldığını göstermektedir (Çokluk, Şekercioğlu ve Büyüköztürk, 2014; Şencan, 2005). Bununla birlikte veri setinin faktör çıkarmaya uygun bir veri seti olup olmadığının belirlenmesi amacı ile yapılan Bartlett küresellik testi sonuçları veri setinin faktör çıkarmaya uygun olduğunu göstermektedir ( $p<.001)$ (Çokluk, Şekercioğlu ve Büyüköztürk, 2014; Şencan, 2005).

Açımlayııı faktör analizi temel bileşenler analizi yöntemi (Tabachnick ve Fidell, 2007) ile yapılmıştır. En sık kullanılan faktörleştirme tekniklerinden olan temel bileşenler analizi veri setinden en yüksek varyansı ortaya çıkarmaya olanak verir (Tabachnick ve Fidell, 2007). Ayrıca açımlayııı faktör analizinde faktörleri isimlendirmede kolaylık sağlayan oblik döndürme yöntemi (Çokluk, Şekercioğlu, Büyüköztürk, 2014) kullanılmışır. Bu aşamadaa oblik döndürme yönteminin kullanılmasının nedeni boyutların birbiri ile ilişkili olmasıdır göstermesidir. Açımlayıcı faktör analizi sürecinde her bir madde için faktör yük değeri $>.45$, ortak faktör varyansı >.30 koşulları gözetilmiştir (Tabachnick ve Fidell, 2007). Açımlayıcı faktör analizi yapııırken ilk olarak kuramsal olarak öngörülen 4 faktörle analiz gerçekleştirilmiştir. Ancak devam eden analizler sonucunda özdeğerleri (eigenvalue) 1'den büyük olan iki faktörlü ve 21 maddelik bir yapıya ulaşılmıştır. Elde edilen ölçeğin faktör öz değerleri, varyans ve yığımlı varyans değerleri Tablo 2'de yamaç birikinti grafiği Şekil 1'de verilmiştir. 
Tablo 2. Faktör Öz Değerleri, Varyans ve Yığımlı Varyans Değerleri

\begin{tabular}{cccc}
\hline Faktör & Özdeğer & Varyans & Yığımlı varyans \\
\hline 1 & 6.90 & 37.54 & 37.54 \\
2 & 3.74 & 13.11 & 50.66 \\
\hline
\end{tabular}

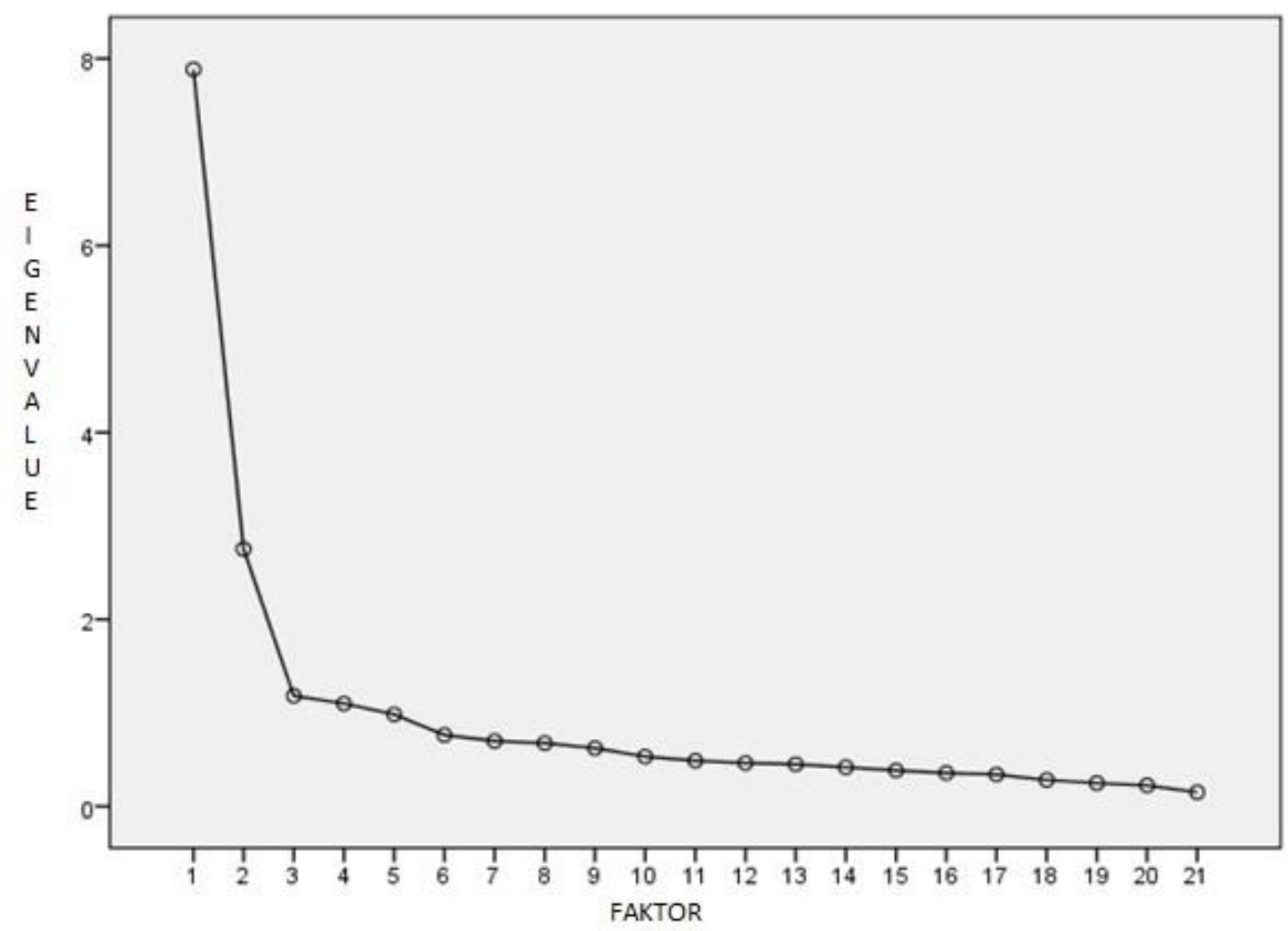

Şekil 1. Faktörlerin Öz Değerleri

Tablo 2'de görüldüğü gibi iki faktörlü yapı toplam varyansın \%50.66'sını açıklamaktadır. Faktörlerin öz değerleri ise sırası ile 6.90 ve 3.74 şeklindedir. Ölçekte yer alan maddelerin faktörlere dağılımı ise Tablo 2'de görüldüğü gibidir. 
Tablo 3. Maddelerin Faktörlere Dağılımı ve Ortak Faktör Varyansları

\begin{tabular}{|c|c|c|c|c|}
\hline Item & Faktör 1 & Faktör 2 & $\begin{array}{l}\text { Ortak } \\
\text { faktör } \\
\text { varyansları }\end{array}$ & $\begin{array}{l}\text { Toplam madde } \\
\text { korelasyonları }\end{array}$ \\
\hline $\begin{array}{l}\text { 21. Bir problem karşısında çözüm yolunu herkesten daha hızıı } \\
\text { bulabilirim }\end{array}$ & .78 & & .61 & .67 \\
\hline 20. Karmaşık olayları anlamak benim için kolaydır & .76 & & .59 & .73 \\
\hline 19. Bir sorun oluşursa onu kısa zamanda çözebilirim & .75 & & .57 & .70 \\
\hline 15. Belirsizlikler karşısında bir çıkış yolu bulmak benim için kolaydır & .70 & & .52 & .65 \\
\hline $\begin{array}{l}\text { 28. Bir sorun karşısında başkalarından daha fazla çözüm yolları } \\
\text { bulurum }\end{array}$ & .69 & & .52 & .65 \\
\hline 27. Bir durumu her zaman çok çabuk kavrayabilirim & .68 & & .46 & .62 \\
\hline 17. Bir olayın nedenlerini kısa zamanda tam olarak anlarım & .67 & & .47 & .62 \\
\hline $\begin{array}{l}\text { 16. İki durum arasında çok az bile olsa benzerlik varsa onu fark } \\
\text { ederim }\end{array}$ & .66 & & .50 & .64 \\
\hline 22. Bir olayın sonuçlarını hızlı bir şekilde tahmin edebilirim & .65 & & .42 & .61 \\
\hline 26. Bir probleme çok sayıda çözüm yolları geliştirebilirim & .65 & & .54 & .57 \\
\hline 18. Beni kandırmak neredeyse imkansızdır & .63 & & .41 & .56 \\
\hline 14. İki durum arasında çok az bile olsa farklılık varsa onu anlarım & .59 & & .47 & .60 \\
\hline 2. Bugüne kadar hayatımda baş edemediğim sorun yoktur & .57 & & .32 & .48 \\
\hline 25. Bir cevap için birden daha fazla soru cümlesi kurabilirim & .55 & & .41 & .57 \\
\hline 24. İki karşıt görüşe karşı üçüncü bir görüş ekleyebilirim & .52 & & .38 & .53 \\
\hline 13. Bir olayın kimsenin göremediği yönlerini görebilirim & .48 & & .35 & .50 \\
\hline 8. Kimsenin değer vermediği fikirlere önem verebilirim & & .81 & .66 & .66 \\
\hline 10. Farklı olduğu düşünülen şeyler arasında benzerlikler görebilirim & & .78 & .67 & .65 \\
\hline $\begin{array}{l}\text { 7. Bir olay karşısında duygu ve düşüncelerim çoğunluktan farklı } \\
\text { olabilir }\end{array}$ & & .76 & .58 & .66 \\
\hline $\begin{array}{l}\text { 11. Benzer olduğu düşünülen durumlar arasında farklııklar } \\
\text { görebilirim }\end{array}$ & & .76 & .65 & .69 \\
\hline 6. Çoğunluğa göre değersiz olan şeyler benim için değerli olabilir & & .73 & .54 & .61 \\
\hline
\end{tabular}

Faktör1: Rasyonellik, Faktör2: Otantiklik.

Tablo 3'de görüldüğü gibi maddelerin faktör yük değerleri. 48 ile .81arasında, ortak faktör varyansları ise. 35 ile .67 arasında değişmektedir. Ölsçekte yer alan birinci faktörde bulunan maddeler Akılcılık Boyutu, ikinci faktör ise öznellik boyutu olarak isimlendirilmiştir.

\section{Doğrulayıcı Faktör Analizi}

AFA analizlerinin ardından ortaya çıkan 2 faktörlü 21 maddelik yapının geçerliği Doğrulayıcı Faktör Analizi ile sınanmıştır. Bu aşamada veri setinin diğer yarısında yer alan 255 kişilik veri seti üzerinde hiçbir modifikasyon yapılmadan birinci düzey DFA analizi gerçekleştirilmiştir. Gerçekleştirilen DFA analizinde 6. "Çoğunluğa göre değersiz olan şeyler benim için değerli olabilir." Ve 7. "Bir olay karşısında duygu ve düşüncelerim çoğunluktan farklı olabilir." Madde; 14. "iki durum arasında çok az bile olsa farkılık varsa onu anlarım." ve 16. "iki durum arasında çok az bile olsa benzerlik varsa onu fark ederim." Maddeler arasında modelin X2 değerine oldukça anlamlı katkı sağlayabilen ve kuramsal açıdan kabul edilebilir bir modifikasyon önerileri ortaya çıkmıştır. Bu öneriler dikkate alınarak madde 6 ve 7 ile madde 14 ve 16 arasındaki ilişki serbest bırakılmıştır. DFA sonucunda elde edilen uyum iyiliği indisleri Tablo 4, yapısal eşitlik modeli ise Şekil 2'de sunulmaktadır. 
Tablo 4. Uyum İyiliği Değerleri

\begin{tabular}{ccc}
\hline & Kabul edilebilir değerler & Modele ait değerler \\
\hline $\mathrm{X} 2$ & $\geq .05$ (Hair et. al., 2006) & .01 \\
$\mathrm{x}^{2} / \mathrm{sd}$ & $\leq 5$ (Sümer, 2000) & 3.39 \\
$\mathrm{RMSEA}$ & $\leq .08$ (Hair et. al., 2006) & .09 \\
$\mathrm{SRMR}$ & $\leq .08$ (Hair et. al., 2006) & .08 \\
$\mathrm{NFI}$ & $\geq .90$ (Hair et. al., 2006) & .92 \\
$\mathrm{NNFI}$ & $\geq .90$ (Hair et. al., 2006) & .94 \\
$\mathrm{CFI}$ & $\geq .90$ (Hair et. al., 2006) & .95 \\
$\mathrm{GFI}$ & $\geq .90$ (Hair et. al., 2006) & .80 \\
$\mathrm{AGFI}$ & $\geq .90$ (Hair et. al., 2006) & .08 \\
\hline
\end{tabular}

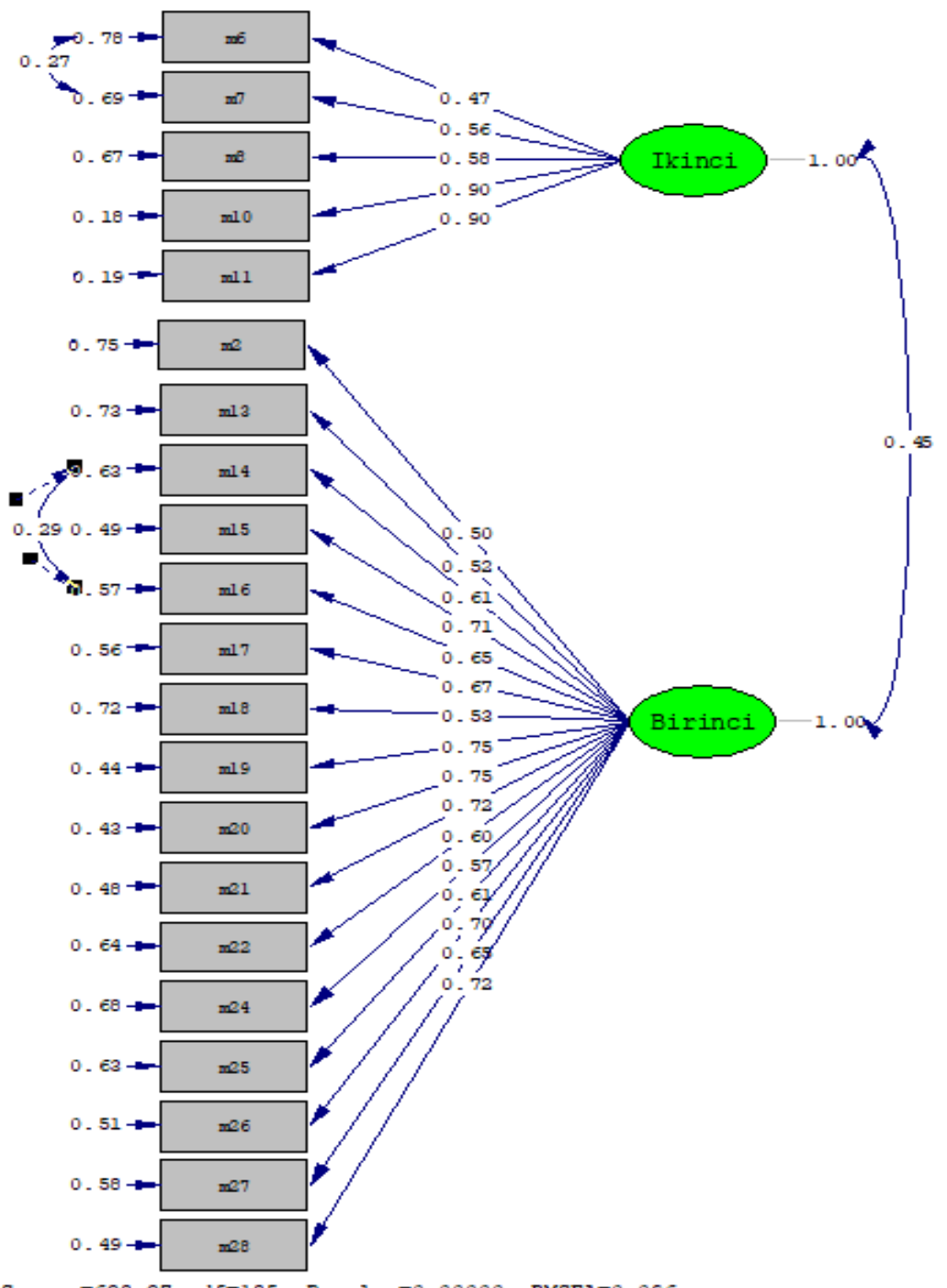

Chi-Square $=628.27, \mathrm{df}=185, \mathrm{P}-\mathrm{value}=0.00000, \mathrm{RMSEA}=0.096$

Şekil 2. Modifikasyon sonrası standart değerler 
Tablo 4 . $t$ ve $\mathrm{R}^{2}$ değerleri

\begin{tabular}{|c|c|c|}
\hline Madde & $t$ değeri & $\mathrm{R} 2$ \\
\hline $\begin{array}{l}\text { 21. Bir problem karşısında çözüm yolunu herkesten daha hızlı } \\
\text { bulabilirim }\end{array}$ & 12.96 & 0.52 \\
\hline 20. Karmaşık olayları anlamak benim için kolaydır. & 13.89 & 0.57 \\
\hline 19. Bir sorun oluşursa onu kısa zamanda çözebilirim. & 13.59 & 0.56 \\
\hline $\begin{array}{l}\text { 15. Belirsizlikler karşısında bir çıkış yolu bulmak benim için } \\
\text { kolaydır. }\end{array}$ & 12.96 & 0.51 \\
\hline $\begin{array}{l}\text { 28. Bir sorun karşısında başkalarından daha fazla çözüm yolları } \\
\text { bulurum. }\end{array}$ & 12.91 & 0.51 \\
\hline 27. Bir durumu her zaman çok çabuk kavrayabilirim. & 11.31 & 0.42 \\
\hline 17. Bir olayın nedenlerini kısa zamanda tam olarak anlarım. & 11.60 & 0.44 \\
\hline $\begin{array}{l}\text { 16. İki durum arasında çok az bile olsa benzerlik varsa onu fark } \\
\text { ederim. }\end{array}$ & 12.21 & 0.43 \\
\hline 22. Bir olayın sonuçlarını hızlı bir şekilde tahmin edebilirim. & 10.33 & 0.36 \\
\hline 26. Bir probleme çok sayıda çözüm yolları geliştirebilirim. & 12.56 & 0.49 \\
\hline 18. Beni kandırmak neredeyse imkânsızdır. & 8.90 & 0.28 \\
\hline 14. i̇ki durum arasında çok az bile olsa farklılık varsa onu anlarım. & 11.27 & 0.37 \\
\hline 2. Bugüne kadar hayatımda baş edemediğim sorun yoktur. & 8.24 & 0.25 \\
\hline 25. Bir cevap için birden daha fazla soru cümlesi kurabilirim. & 10.55 & 0.37 \\
\hline 24. İki karşıt görüşe karşı üçüncü bir görüş ekleyebilirim. & 9.79 & 0.32 \\
\hline 13. Bir olayın kimsenin göremediği yönlerini görebilirim. & 8.95 & 0.27 \\
\hline 8. Kimsenin değer vermediği fikirlere önem verebilirim. & 10.24 & 0.33 \\
\hline $\begin{array}{l}\text { 10. Farklı olduğu düşünülen şeyler arasında benzerlikler } \\
\text { görebilirim. }\end{array}$ & 17.71 & 0.82 \\
\hline $\begin{array}{l}\text { 7. Bir olay karşısında duygu ve düşüncelerim çoğunluktan farklı } \\
\text { olabilir. }\end{array}$ & 9.91 & 0.31 \\
\hline $\begin{array}{l}\text { 11. Benzer olduğu düşünülen durumlar arasında farklııılar } \\
\text { görebilirim. }\end{array}$ & 17.52 & 0.81 \\
\hline 6. Çoğunluğa göre değersiz olan şeyler benim için değerli olabilir. & 8.32 & 0.22 \\
\hline
\end{tabular}

\section{Ölçüt Geçerliği}

Ölçüt geçerliğini belirlemek için, geliştirilen ölçek ile Düşünme Stilleri Ölçeği'nin öznellik ve ayırt edicilik alt boyutları arasındaki ilişkiler incelenmiştir.

Tablo 5. Ölçekler Arası Korelasyonlar

\begin{tabular}{cccccc}
\hline & Faktör1 & Faktör2 & Toplam & Ayırt edicilik & Öznellik \\
\hline Faktör1 & 1 & & & & \\
Faktör2 &, $450^{* *}$ & 1 & & & \\
Toplam &, $958^{* *}$ &, $686^{* *}$ & 1 & 1 & 1 \\
Ayırt edicilik &, $487^{* *}$ &, $455^{* *}$ &, $542^{* *}$ &, $393^{* *}$ & 1 \\
Öznellik &, $521^{* *}$ &, $417^{* *}$ &, $558^{* *}$ & & \\
\hline
\end{tabular}

$* *(p<.01)$.

Görüldüğü üzere geliştirilen ölçeğin tüm alt boyutları ve toplam puanları ölçüt geçerliği için kullanılan Düşünme Stilleri Ölçeği'nin alt boyutları ile ilişsilidir. 


\section{Güvenirlik}

Ölçeğin güvenirliğinin değerlendirilmesi için Cronbach $\alpha$ değerleri hesaplanmıştır. Cronbach $\alpha$ değerleri Tablo 5 'de görüldüğü gibidir.

Tablo 5. Cronbach Alfa Değerleri

\begin{tabular}{cc}
\hline Faktör & Cronbach $\alpha$ \\
\hline Toplam Puan & .92 \\
Faktör1 & .91 \\
Faktör2 & .85 \\
\hline
\end{tabular}

Tablo 5'de görüldüğü gibi alt boyutlar ve ölçeğin geneli bazında, iç tutarlık katsayılarının .80 ve üzerinde olduğu görülmektedir. Bu durum alan yazında kabul edilebilir bir güvenirliğe işaret etmektedir (Hair ve diğerlei, 2006). Elde edilen düzeltilmiş madde-toplam korelasyonları da (Tablo 2) .50 ve üzerinde bulunmuştur. Bu durum iç tutarlığının varlığına ayrı bir kanıt oluşturmaktadır.

\section{SONUÇ ve TARTIŞMA}

Eğik rotasyon yöntemine dayanan açımlayıcı faktör analizi sonucunda 2 faktörlü bir bileşen ortaya çıkmıştır. Bu faktörler otantiklik (5 madde) ve rasyonellik (16 madde) olarak tanımlanmıştır. Maddeler için faktör yükleri .48 ile .81 arasında değiş̧mektedir ve ölçek \% 50.66'lık bir varyansa sahiptir. Doğrulayıcı faktör analizi sonucunda elde edilen sonuçlar kabul edilebilir seviyededir. Geliştirilen ölçeğin ölçüt geçerliği sonuçları incelendiğinde sonuçların anlamlı düzeyde olduğu görülmüştür $(p<.01)$. Tüm bu veriler bir arada değerlendirildiğinde geliştirilen ölçeğin yetişkin bireylerin ıraksak düşünme eğilimlerini ölçtüğü yorumu yapılabilir.

Bir öz-değerlendirme aracı olarak geliştirilen ıraksak düşünme öz-değerlendirme ölçeğinin otantiklik ve rasyonellik olarak iki alt boyutu vardır. Öte yandan, ölçek üzerinde esneklik ve detaylandırma alt boyutları yer almamakta olup, bu durum ölçeğin bir sınırlaması olarak kabul edilebilir. Çünkü literatürde Guilford'un (1982) performans değerlendirme ölçeği olarak geliştirilen farklı düşünme öz değerlendirme ölçeği rasyonellik, esneklik, otantiklik ve detaylandırma alt boyutlarını içermektedir.

Bu çalışmadan elde edilen ölçek, bireylerin ıraksak düşünme becerilerini değerlendirmelerini sağlar. Özellikle, yaratıcılık ile ilgili farklı düşünme becerilerini değerlendiren ölçüm araçlarının sayısının arttırılması, konu ile ilgili modellerin ve teorilerin geliştirilmesine olanak sağlayabilir. Yaratıcılığın geliştirilmesi için psikometrik yaklaşımın katkısı sağlanmalıdır (Zeng ve ark. 2011). Farklı düşünme becerileri için geliştirilen performans testlerine ek olarak, öz değerlendirme araçları da yaratıcılık teorilerine katkıda bulunabilir. Bazı çalışmalar öz değerlendirme ve performans değerlendirmesi arasında güçlü bir korelasyon olduğunu göstermiştir (Pintrich ve Groot, 1990), bazıları ise öz değerlendirme ve performans değerlendirmesi arasında bir korelasyon olmadığını göstermiştir (Brackett ve ark. 2006). Daha sonraki çalışmalarda Iraksak Düşünme Öz Değerlendirme Ölçeği ile ıraksak 
düşünme üzerine performans değerlendirme ölçekleri arasında bir ilişki olup olmadığı ortaya konulabilir. Iraksak Düşünme Öz Değerlendirme Ölçeği'nin yaratıcılık ve ıraksak düşünme ile ilgili çalışmalara katkıda bulunacağı düşünülmektedir.

\section{ETiK}

Bu makalede dergi yazım kurallarına, yayın ilkelerine, araştırma ve yayın etiği kurallarına, dergi etik kurallarına uyulmuştur. Makale ile ilgili doğabilecek her türlü ihlallerde sorumluluk yazarlara aittir.

\section{KAYNAKÇA}

Althuizen, N., Wierenga, B. ve Rossiter, J. (2010). "The Validity of Two Brief Measures of Creative Ability." Creativity Research Journal, 22(1): 53-61.

Aslan, E. (2001). "Torrance Yaratıcı Düşünce Testi'nin Türkçe Versiyonu." M.Ü. Atatürk Eğitim Fakültesi Eğitim Bilimleri Dergisi. 14: 19-40.

Baer, J. (2011). "How Divergent Thinking Tests Mislead Us: Are the Torrance Tests Still Relevant in the 21st Century? The Division 10 debate". Psychology of Aesthetics, Creativity, and the Arts. 5(4): 309-313.

Bowden, E. M. ve Jung-Beeman, M. (2003). "Normative Data for 144 Compound Remote Associate Problems." Behavior Research Methods, Instruments ve Computers, 35(4): 634-639.

Brackett, M. A., Rivers, S. E., Shiffman, S., Lerner, N. ve Salovey, P. (2006). "Relating Emotional Abilities to Social Functioning: A Comparison of Self-report and Performance Measures of Emotional Intelligence." Journal of Personality and Social Psychology, 91(4): 780-795. doi.org/10.1037/0022-3514.91.4.780

Büyüköztürk, Ş. (2002). “Faktör analizi: Temel kavramlar ve Ölçek Geliştirmede Kullanımı.” Kuram ve Uygulamada Eğitim Yönetimi, 32: 470-483.

Büyüköztürk, Ş. (2011). Sosyal Bilimler İ̧̧in Veri Analizi El Kitabı. Ankara: Pegem Akademi Yayıncılık.

Child, D. (2006). The Essentials of Factor Analysis. London: Continuum.

Cohen, R.J. ve Swerdlık, M.E. (2015). Psikoloik Test ve Değerleme. Çev: Ezel Tavşancıl. Ankara: Nobel Yayınları.

Çokluk, Ö., Şekercioğlu, G. ve Büyüköztürk, Ş. (2014). Sosyal Bilimler İ̧̧in Çok Değiş̧enli istatistik SPSS ve LISREL Uygulamaları. Ankara: PEGEM Akademi Yayıncılık.

Diedrich, j., Jauk, E., Silvia, P. J., Gredlein, J.M., Neubauer, A.C. ve Benedek, M. (2018) Assessment of Real-Life Creativity: The Inventory of Creative Activities and Achievements (ICAA). Psychology of Aesthetics, Creativity, and the Arts. 12 (3)304-316

Ferrandiz, C., Ferrando, M., Soto, G., Sainz, M. ve Prieto, D.M. (2017). “Divergent Thinking and Its Dimensions: What We Talk About and What We Evaluate?" Anales de Psicologia. 33 (1): 40-47.

Guilford, J.P. (1982). “Cognitive Psychology's Ambiguities, Some Suggested Remedies.” Psychological Review. 89(1): 48-59.

Güngör, D. (2016). "Psikolojide Ölçme Araçlarının Geliştirilmesi ve Uyarlanması Kılavuzu." Türk Psikoloji Yazıları, 19 (38): 104-112.

Dirlik, M.E. (2014). “Ölçek Geliştirme Konulu Doktora Tezlerinin Test ve Ölçek Geliştirme Standartlarına Uygunluğunun İncelenmesi." Eğitimde ve Psikolojide Ölçme ve Değerlendirme Dergisi, 5(2): 62-78. 
Erkuş, A., Sünbül, A., Sünbül, S.Ö., Yormaz, S. ve Aşiret, S. (2017). Psikolojide Ölçme ve Ölçek Geliştirme II. Ankara: Pegem Akademi.

Hair, Jr., J. F., Black, W. C., Babin, B. J., Anderson, R. E. ve Tatham, R. L. (2006). Multivariate Data Analysis (6th ed.). Upper Saddle River, NJ: Pearson Prentice Hall.

Hawthorne G., Saggar, M., Quintin, E.M., Bott N., Keinitz, E., Liu, N., Chien, Y.H., Hong, D., Reiss, A.L. (2016) Designing a Creativity Assessment Tool for the Twenty-First Century: Preliminary Results and Insights from Developing a Design-Thinking Based Assessment of Creative Capacity. Design Thinking Research. 111-123. doi.org/10.1007/978-3-319-19641-1_8.

Heller, K.A. (2004). "Identification of Gifted and Talented Students." Psychology Science, 46(3): 302 - 323.

Kaufman, J. C. (2002). Creativity and Confidence: Price of Achievement": Comment. American Psychologist. 57(5): 375-376.

Karakoç, F.Y. ve Dönmez, L. (2014). Ölçek Geliştirme Çalışmalarında Temel illkeler. Tıp Eğitimi Dünyası. 5 (40): 39-49.

Lee, Y. J. (2004). Effects of Divergent Thinking Training/Instructions on Torrance Tests of Creative Thinking and Creative Performance. Doktora Tezi, University of Tennessee.

Lucas, B. (2016) A Five-Dimensional Model of Creativity and its Assessment in Schools. Applıed Measurement In Education. 29 (4) 278-290.

Mednick, S. A. (1968). “The Remote Associates Test.” The Journal of Creative Behavior, 2(3): 213-214.

Özen, G., Doğan, A. ve Cinan, S. (2015). “Uzak Bağlantılar Testi: Norm ve Güvenirlik Çalışması.” Psikoloji Çalışmaları Dergisi, 35:2-25.

Pintrich, P. R. ve De Groot, E. (1990). “Motivational And Self-Regulated Learning Components Of Classroom Academic Performance." Journal of Educational Psychology, 82(1): 33-40

Reisman, F., Keiser, L., Otti, O. (2016) Development, Use and Implications of Diagnostic Creativity Assessment App, RDCA - Reisman Diagnostic Creativity Assessment. Creatıvity Research Journal, 28(2) 177-187.

Shen, T., Lai, J.C. (2014). "Exploring the Relationship between Creative Test of ATTA and the Thinking of Creative Works" Procedia-Social and Behavioral Sciences (112): 557-566.

Siegel, J. ve Bugg, J. M. (2016). “Dissociating Divergent Thinking and Creative Achievement by Examining Attentional Flexibility and Hypomania." Psychology of Aesthetics, Creativity, and the Arts, 10(4): 416424.

Soper, D.S. (2017). “A-priori Sample Size Calculator for Structural Equation Models Software.” Available from http://www.danielsoper.com/statcalc

Sümer, N. (2000). "Yapısal Eşitlik Modelleri: Temel Kavramlar ve Örnek Uygulamalar.” Türk Psikoloji Yazıları, 3(6): 49-74.

Sünbül, A.M. (2004). “Düşünme Stilleri Ölçeğinin Geçerlik ve Güvenirliği.” Eğitim ve Bilim, 29 (132): 25-42.

Tabachnick, B. G. ve Fidell, L. S. (2007). Using Multivariate Statistics. New York: Pearson Education.

Zeng, L., Proctor, R.W. ve Salvendy, G. (2011). “Can Traditional Divergent Thinking Tests be Trusted in Measuring and Predicting Real-World Creativity?" Creativity Research Journal, 23:1, 24-37. 